\title{
A Structural Equation Model of Factors Influencing Academic Administrative Effectiveness: A Study in Thai Schools Context
}

\author{
Chuchat Hongkhao \\ Somkid Sroinam \\ Phoom Praraksa \\ Department of Educational Administration \\ Udon Thani Rajabhat University \\ Thailand
}

\begin{abstract}
The academic administrative effectiveness has been the important problem of Thai schools especially the educational opportunity expansion schools in northeast of Thailand that needed solving. This research aimed to examine the model goodness of fit offactors influencing academic administrative effectiveness and investigate direct, indirect and total effect of these factors. The 710 school directors were selected by multi-stage random sampling from educational opportunity expansion schools in northeast of Thailand in academic year 2017. The data were collected using the 5-level rating scale questionnaire and then analyzed by confirmatory factor analysis and structural equation model for testing the goodness of fit index of the hypothetical model with empirical data. The results indicated the model was valid and fit to the empirical data with direct, indirect, and total effect of the factors. The research application was discussed finally.
\end{abstract}

Keywords: Academic Administrative Effectiveness, Causal Factors, Structural Equation Model

\section{Introduction}

The article 54 of the Constitution of the Kingdom of Thailand B.E. 2560 (2017) requires all children to be educated for twelve years. The state has the duty to supervise, promote and support the educational management. All education must focus on the development of students as well as discipline, pride in the country and expertness according to their aptitude, and responsibility for families, communities, society and the nation )Government Gazette. ,2017). The government has a very supportive policy affects the school population and disadvantaged students have the opportunity to receive higher level of education. In addition, the government accelerates the decentralization of management to educational institutions in order to effectively manage the educational institutions because of problems in teaching, management and spending the educational budget)Office of the Education Council, 2016).

The article 39 of the National Education Act B.E. 2542 (1999) and as amended determined the structure system management. There is decentralization to the Educational Service Area Offices also academic, budget management, personnel management, and general administration) Office of the National Education Commission, 2003). Furthermore, The Ministerial Regulation on the Establishment of Rules and Procedures for the Decentralization of Educational Administration specifies Academic Management is the heart of school administration. It is the main management that involves the quality of the learner (the Government Gazette, 2007). This act is consistency with the Office of the Basic Education Commission (2004) stated that academic administration is the primary task of school administrators to work on the quality of students in both quantitative and qualitative. Moreover, Phuprasert (2001) told that academic administration involves the development of learners to the expected quality. Academic administration in schools is Management related to the development of quality education, which is the ultimate goal of the school mission. This state is similar to Bunprasert (2003) explains that academic work is the main task which is the largest work of the system and the heart of the school. The educational opportunity expansion schools under the Office of the Basic Education Commission first opened in 1990 that taught primary and secondary level. 
This type of schools has had purpose to provide the students who finish primary level and cannot study at secondary schools under the Department of General Education have a chance to study at this level. In 2017, there were 7,072 educational opportunity expansion schools in Thailand that was a large number (Office of the Basic Education Commission, 2017). However, these schools still have obstacles for development especially academic administration of schools. Most schools have the lower than 50\% of Ordinary National Education Test (O-NET) score. Moreover, the Programme for International Student Assessment (PISA) indicates that the average score of Thai students aged 15 years is lower than the international average for all subjects. Thailand is ordered at the 55th from 72 countries that lower than many countries in Association of South East Asian Nations: ASEAN (Office of the Education Council, 2016)

According to the above importance, this research tried to examine the model goodness of fit of factors influencing academic administrative effectiveness and investigate direct, indirect and total effect of factors influencing academic administrative effectiveness of educational opportunity expansion schools in northeast of Thailand. This may lead to understand the ways to develop academic administration of educational opportunity expansion schools that is the path to change and shift educational quality for disadvantaged learners.

\section{Method}

\subsection{Participants}

The participants in this research consisted of 710school directors were selected by multi-stage random sampling from educational opportunity expansion schools in northeast of Thailand in academic year 2017.The sample size was employed by $\mathrm{G}^{*}$ Power3 and then, multi-stage random sampling was used to select the sample.

\subsection{Measures}

The instrument used in this study was a questionnaire comprised 3 parts consisted of background data of the participants, administrative effectiveness, and the factors influencing academic administrative effectiveness of educational opportunity expansion schools in northeast of Thailand.

Part 1was the list to inquire general data of the participants that consisted of gender, age, education and work experience at the current position.

Part 2 was the 5 level of rating scale questions about academic administrative effectiveness with the reliability of 0.939. The questionnaire composed of 1) learners' quality 2) curriculum development 3) parents' satisfaction and 4) educational measurement and evaluation.

Part 3 composed of the 5 level of rating scale questions with the reliability of 0.937 . The questionnaire consisted of 1) administrators' instructional leadership 2) participative administration3) professional learning community 4) instructional management and 5) school commitment

\subsection{Procedure and design}

This study was a survey research collecting data by a questionnaire. The data was collected by mail after the researcher has sent the letters to the target schools. The questionnaires were proposed to the school administrators and defined the return date.

\subsection{Statistical analysis}

The data was analyzed by using Statistical Package Software. First, the descriptive statistics was applied for frequency, percentage, mean, standard deviation, skewness, kurtosis, Kaiser-Meyer-Olkin (KMO) Test for Sampling Adequacy, Bartlett's sphericity test, Pearson product-moment correlation coefficient. Then, Confirmatory Factor Analysis was employed to validate measurement model and Structural Equation Model was applied to test the model fit.

\section{Results}

3.1 The model of factors influencing academic administrative effectiveness of the educational opportunity expansion schools in northeast was valid and fit to the empirical data. The model indicated the Chi-square goodness of fit was $\chi^{2}=127.90, \mathrm{df}=106, \mathrm{p}=0.073$, GFI $=0.98, \mathrm{AGFI}=0.96, \mathrm{RMSEA}=0.017, \mathrm{SRMR}=0.017$ and $\mathrm{CN}=745.99$.In addition, the standardized coefficient of factor loading of all observes variables were at the level of significance 0.01 with the value of $0.67-0.92$ that meant the model was measured by all of indicators. This portrayed the strong evidence of construct validity of the measurement model. 
Moreover, the coefficient of determination $\left(R^{2}\right)$ of all observes variables showed $45 \%-85 \%$ explaining the variance of the model as Table 1 and figure 1 .

Table 1.Parameter estimation of observed variables

\begin{tabular}{|c|c|c|c|c|c|c|}
\hline \multirow{2}{*}{ Variables } & \multicolumn{4}{|c|}{ Factor Loading } & \multirow{2}{*}{ Factor Score } & \multirow{2}{*}{$\mathbf{R}^{2}$} \\
\hline & b & SE & $\mathbf{t}$ & $\beta$ & & \\
\hline \multicolumn{7}{|l|}{ LY matrix } \\
\hline DS & 1.00 & - & - & 0.81 & 0.08 & 0.65 \\
\hline DO & $1.16^{* *}$ & 0.04 & 30.77 & 0.89 & 0.10 & 0.79 \\
\hline $\mathrm{BN}$ & $1.13^{* *}$ & 0.04 & 26.95 & 0.86 & 0.22 & 0.75 \\
\hline $\mathrm{PE}$ & $1.03 * *$ & 0.04 & 26.38 & 0.85 & 0.23 & 0.73 \\
\hline $\mathrm{LN}$ & 1.00 & - & - & 0.89 & 0.39 & 0.80 \\
\hline $\mathrm{CT}$ & $1.12 * *$ & 0.03 & 32.56 & 0.87 & 0.17 & 0.76 \\
\hline $\mathrm{RS}$ & $0.96 * *$ & 0.03 & 28.24 & 0.84 & 0.17 & 0.71 \\
\hline $\mathrm{CL}$ & 1.00 & - & - & 0.85 & 0.16 & 0.72 \\
\hline $\mathrm{SC}$ & $1.04 * *$ & 0.04 & 25.33 & 0.80 & 0.18 & 0.64 \\
\hline $\mathrm{TS}$ & $1.02 * *$ & 0.04 & 24.37 & 0.78 & 0.04 & 0.60 \\
\hline MT & $1.02 * *$ & 0.04 & 23.75 & 0.79 & 0.16 & 0.62 \\
\hline $\mathrm{DE}$ & 1.00 & - & - & 0.85 & 0.49 & 0.73 \\
\hline $\mathrm{AG}$ & $1.01 * *$ & 0.04 & 28.26 & 0.89 & 0.35 & 0.78 \\
\hline $\mathrm{CI}$ & $0.97 * *$ & 0.04 & 27.56 & 0.91 & 0.50 & 0.82 \\
\hline $\mathrm{CU}$ & 1.00 & - & - & 0.80 & 0.10 & 0.64 \\
\hline IN & $1.05 * *$ & 0.04 & 28.69 & 0.92 & 0.42 & 0.85 \\
\hline EV & $0.99 * *$ & 0.04 & 25.07 & 0.88 & 0.40 & 0.77 \\
\hline QS & $0.90 * *$ & 0.05 & 19.33 & 0.67 & 0.06 & 0.45 \\
\hline SA & $0.97 * *$ & 0.04 & 23.63 & 0.79 & 0.01 & 0.63 \\
\hline \multicolumn{7}{|l|}{ LX matrix } \\
\hline $\mathrm{AC}$ & $0.42 * *$ & 0.02 & 26.86 & 0.84 & 0.24 & 0.71 \\
\hline PD & $0.41 * *$ & 0.02 & 25.61 & 0.81 & 0.42 & 0.66 \\
\hline DI & $0.45^{* *}$ & 0.02 & 27.15 & 0.85 & 0.32 & 0.72 \\
\hline $\mathrm{CM}$ & $0.44 * *$ & 0.02 & 27.37 & 0.85 & 0.13 & 0.72 \\
\hline
\end{tabular}

\section{$\chi^{2}=127.90, \mathrm{df}=106, p=0.073, \mathrm{GFI}=0.98$, AGFI $=0.96$, RMSEA $=0.017$, SRMR $=0.017$ and $\mathrm{CN}=745.99$}

** Significance level of 0.01

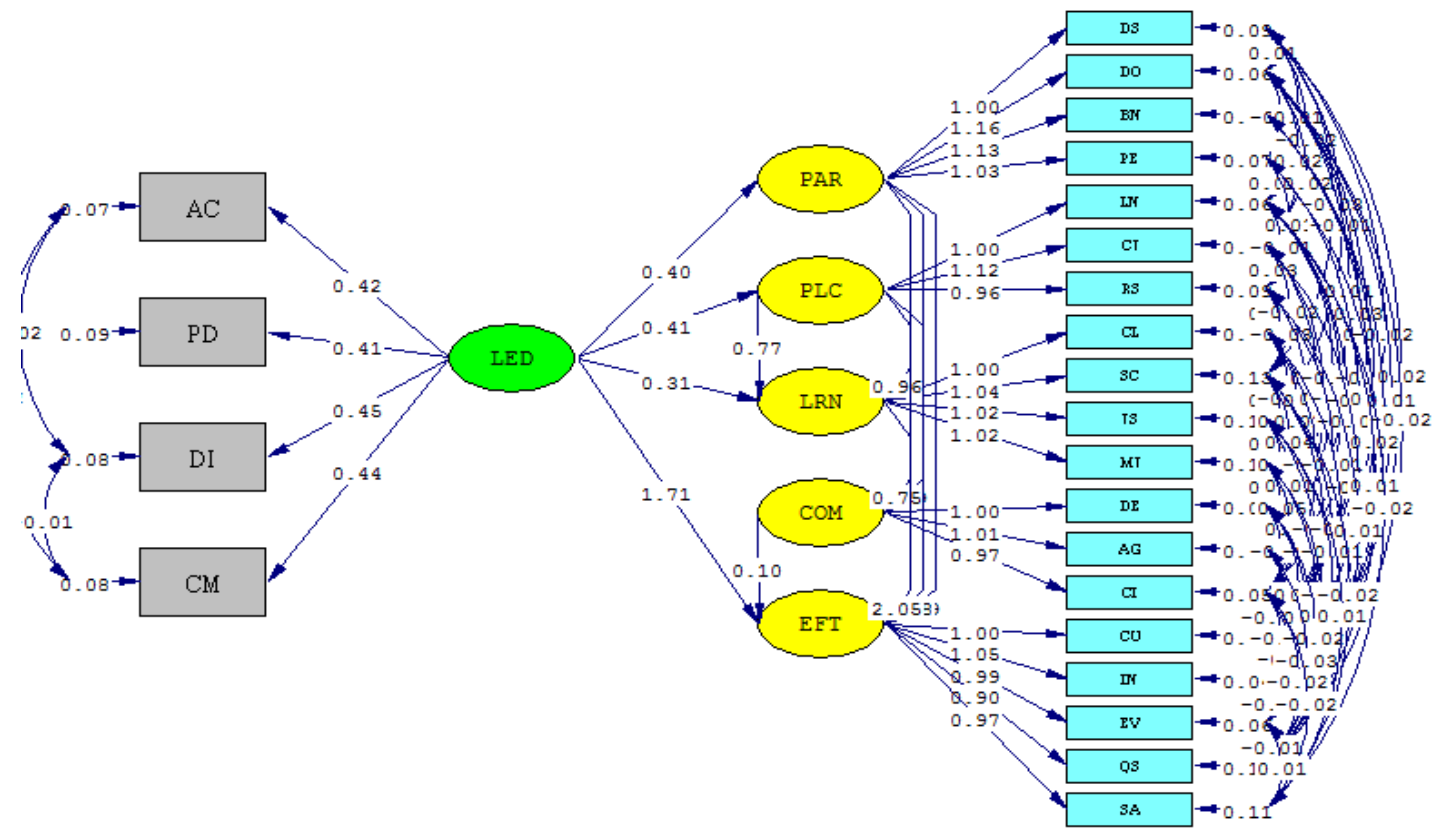

Chi-Square $=127.90, \mathrm{df}=106, \mathrm{P}-\mathrm{value}=0.07260, \mathrm{RMSEA}=0.017$

Figure 1.The model of academic administrative effectiveness 
3.2 The factors having effect to academic administrative effectiveness of the educational opportunity expansion schools in northeast consisted of 1) two factors of direct effect were administrators' instructional leadership and instructional management 2) two factors of indirect effect were administrators' instructional leadership and professional learning community and 3 ) four factors of total effect were administrators' instructional leadership, professional learning community, participative administration and instructional management. In addition, the model accounted for $95 \%$ of variance in academic administrative effectiveness of the educational opportunity expansion schools in northeast as Table 2 and figure 2.

Table 2.Direct effect, indirect effect and total effect of model of factors influencing academic administrative effectiveness of the educational opportunity expansion schools in northeast of Thailand

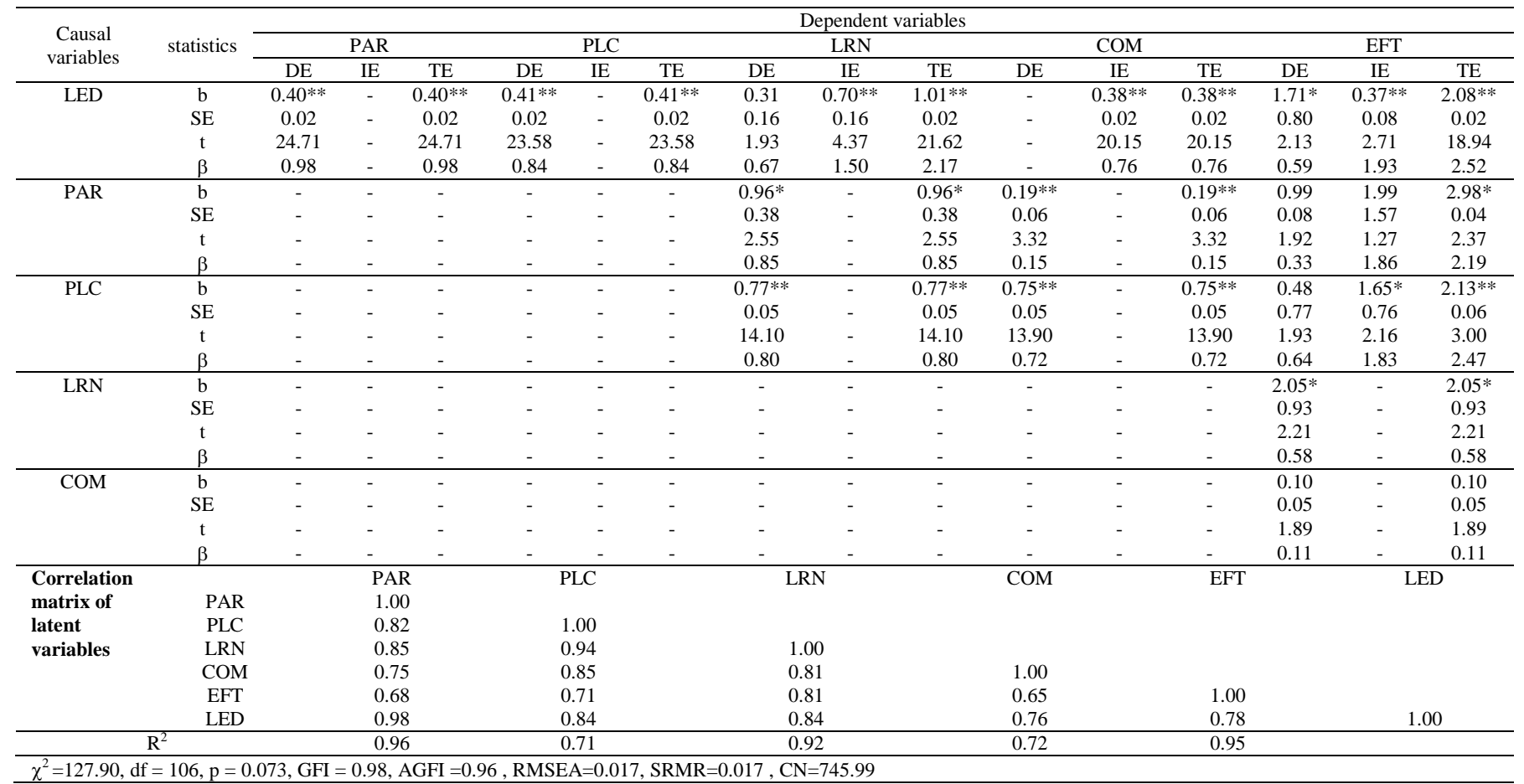

** Significance level of $0.01, *$ Significance level of 0.05
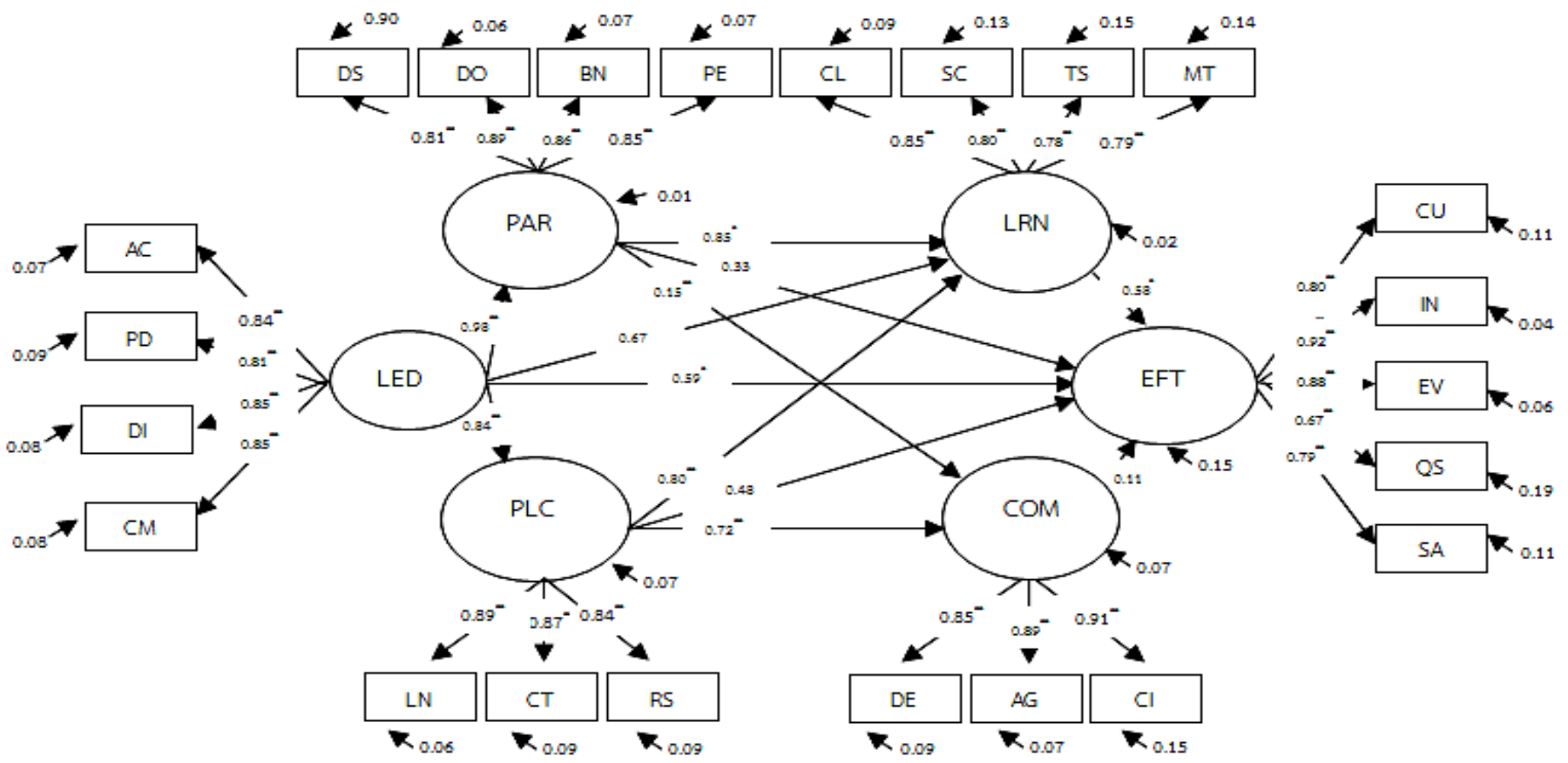

Figure 2.A Structural Equation Model of Factors Influencing Academic Administrative Effectiveness 


\section{Discussion and Conclusion}

4.1 A structural equation model of factors influencing academic administrative effectiveness of the educational opportunity expansion schools in northeast of Thailand was valid and fit to the empirical data. The model indicated the Chi-square goodness of fit was $\chi^{2}=127.90$, $\mathrm{df}=106, \mathrm{p}=0.073$, GFI $=0.98$, AGFI $=0.96$, $\mathrm{RMSEA}=0.017, \mathrm{SRMR}=0.017$ and $\mathrm{CN}=745.99$. In addition, the model accounted for $95 \%$ of variance. The statistics value portrayed the strong evidence of the model fit. This may be the administrators' instructional leadership, participative administration; professional learning community and instructional management are the important factors affect academic administrative effectiveness of the educational opportunity expansion schools. This result corresponded to Phonburee (2008) found that factors affecting academic administration of school administrators of Nongbualamphu Educational Service Area Office consists of technological for education factor, school administrators factor, teachers factor, parental and community factors, building facility factor, management factors, media and educational technology factor, and budgetary factors. In addition, Nawasit (2010) indicated that factors influencing the academic success of the learners included teacher commitment, teacher ability perception and transformational leadership of school administrators.

4.2 Factors influencing academic administrative effectiveness of the educational opportunity expansion schools in northeast of Thailand.

4.2.1 Administrators' instructional leadership (LED) had direct influence, indirect influence and total influence on academic administrative effectiveness. This may be the school administrators are leaders in school activities. In order to achieve the goals of the school, they must have the knowledge and skills especially the skills and knowledge in education and instruction. Therefore, the important function of the school administrators is to pay attention at teaching management. However, the role of the school administrators may be different from good teachers that are the school administrators should display the role of teaching leaders or academic leaders (instructional leadership) (Hoy \& Miskel, 2008). This result is consistent to Tatong (2017) studied the factors affecting the academic administration of the schools under the jurisdiction of Loei Primary Education Service Area Office 2. The research result found that academic leadership of school administrators, characteristics of good teachers, and the participation of the community had a significant effect on the effectiveness of the academic administration of the schools under Loei Primary Education Area Office 2 at the .01 level of significance.

4.2.2 Instructional management (LRN) had direct influence and total influence on academic administrative effectiveness. This may be the learning process is a factor that affects the quality of the school, including the process of learning focusing on the learner and the learning atmosphere that is conducive to quality development. (Chantawanich, 2008). Learning management for knowledge-based learners, competency based learning standards, core competencies and desirable characteristics as defined in core curriculum. Learners are the most important and believe that everyone has the ability to learn and develop themselves. This result corresponded to Thongsawat (2003) synthesized the research to synthesize factors influencing the effectiveness of school administration. The research finding indicated that factors influencing the effectiveness of school administration consisted of classroom atmosphere, quality of teaching, leadership, school atmosphere and facilities.

4.2.3 Professional learning community (PLC) had indirect influence on academic administrative effectiveness. This may be PLC is the best way to improve and develop students' performance. The educational management must meet the needs of school truly and must collaborate with parents based on three principles including focusing on learning, cooperation culture and focusing on results. It must be a professional learning community (Jessie, 2007). In addition, Du Four (2002) stated that collaboration in schools to find best practices in developing classroom learning is a professional learning community (PLC) by the synergy between teachers, administrators, parents and students. In addition, The paree (2014) said that the professional development of teachers had 3 skills which are skills for 21st-century learners. Furthermore, Pongsriwat (2013) stated that the development of educational institutions as learning institutions, one of the most important factors that must be met is to have a professional learning community. This is similar to Saisanitsareekul (2014) shown that the effective way to improve the quality of education to meet the needs of the students themselves and society was building a professional learning community (PLC) as part of a school-based administration.

\section{Recommendations}

Related organizations should promote academic leadership of school administrators and instructional management. 
It should focus on creating a professional learning community because it has direct influence and indirect influence on the effectiveness of academic administration of educational opportunities expansion schools in the northeast of Thailand. In addition, the schools should focus on improving the quality of learners and the learning process because it was found both factors have the lowest mean. It can be seen that the process of learning is related to the quality of learners. If the school organizes the learning process effectively, it will meet the higher quality students. Future research should study and develop innovations or models to promote each factor so that the schools will have clear guidelines for promoting such factors. This will result in the academic administration of the educational opportunity expansion schools in northeast of Thailand more effective to context.

\section{References}

Atthanark, S. \&Uthairat, A. (2016).State and Problems of Academic Administration in Educational Opportunity Expansion Schools under Ubon Ratchathani Educational Service Area Office 3.Journal of Lotus Graduate, Ubon Ratchathani Rajabhat University, (1) 16, .278-265

Blau, I. \& Presser, O. (2013).e-Leadership of school principals: Increasing school effectiveness by a school data management system. British Journal of Educational Technology,1-20. doi:10.1111/bjet.12088

Bunprasert, U. (2003). School-based management administration. Bangkok: Center for Textbooks and Academic Documents, Faculty of Education, Chulalongkorn University.

Chantawanich, A. (2008). Administrative Guidelines and Development of Schools to Quality Schools. Bangkok: Prikwaan Graphic.

"Constitution of Thailand B.E. ."2560(April 6, 2017). Government Gazette. Volume 134, part 40.

Dufour, R. (2002). Time, Perspective and Priorities.In Eaker, R., Dufour, R. \&Burnette, R. (2002). Getting Started: Reculturing Schools to Become Professional Learning Communities (Solutions). National Educational Service, Bloomington, Indiana.

Heneveld, W. (1994).Planning and monitoring the quality of primary education in subsaharan Africa. Washington DC: World Bank, Human Resources and Poverty Division.

Hoy, W. K., \&Miskel, C. G.(2008). Educational administration: Theory research and practice. $8^{\text {th }}$ ed. New York: McGraw-Hill.

Jessie, L.G. (2007). The Elements of a Professional Learning Community:Professional learning communities will change how you and your staff viewlearning. Leadership Compass, 5(2), 1-3.

Jittri, J. (2013).Effectiveness of Academic Administration in Educational Opportunity Expansion Schools under Nakhonsrithammarat Primary Educational Service Area Office 3.Journal of Graduate, 11 (55), 35-44.

Kangpeng, S. (2003).Principles of participatory theories in organization.Bangkok: Chuan Printing. . (2008).Administrative Factors Influencing School Effectiveness: Developing and Validating the Model. Dissertation of Educational Administration, Khonkaen University.

Kyriakides, L., Creemers, B. Antoniou, P. \&Demetriou, D. (2010). A synthesis of studies searching for school factors: implications for theory and research. British Educational Research Journal, 36(5), 807-830.

"Ministerial Regulation on the Establishment of Rules and Procedures for the Decentralization of Educational Administration and Management B.E. 2550 (May 16, 2007). Government Gazette.Volume 124 part 24.

Nawasit, S. (2010).A Study of Linear Structural Equation Model of Factors Affecting Academic Achievement of Students in Schools under the Educational Service Area Office in the Northeast. Dissertation of Educational Administration, LoeiRajabhat University.

Nir, A. E. (2002). School-based management and its effect on teacher commitment. International Journal of Leadership in Education, 5(4): 323-341.

Office of the Basic Education Commission.(2004). Basic School Board Operation Manual. Bangkok: Ministry of Education. (2009).Teacher's Manual for Teachers Performance under the Office of the Basic Education Commission. Bangkok: Agricultural Cooperative Federation of Thailand. .(2017).Information Management for Educational Institutions.Retrieved June $3^{\text {rd }}, .2016$ From http://data.bopp-obec.info/emis/area_school.php.

Office of the Education Council. (2016). The National Education Plan, 2016 - 2036. Retrieved June $16^{\text {th }}, 2016$ fromhttp://www.moe.go.th. 
Office of the National Education Commission. (2003). National Education Act B.E. (1999) 2542 and Amendments (No.2) B.E. 2545 Bangkok: The Office of the Prime Minister.

Panich, W. (2016).Entertainment of teachers lives to the learning community. Bangkok: SR Printing Mass Product.

Pressley, M. Rankin, J., \& Yokoi, L. (1996). A survey of instructional practices ofprimary teachers nominated as effective in promoting literacy. The ElementarySchool Journal, 96(4): 363-384.

Phonart, P. (2014). Strategic for Development of Educational Opportunity Expansion Schools in Kamphaengphet Province to be a learning organization.Journal of Education, Naresuan University, (1) 16, .39-24

Phonburee, T. (2008).Factors Affecting Academic Administration of School Administrators under NongBua Lam Phu Primary Educational Service Area Office.Thesis of Master of Educational Administration.Udon ThaniRajabhat University.

Phuprasert, K. (2001). Academic Administration in Educational Institutions. Bangkok: Tips Publication.

Pongsriwat, S. (2013).School leaders and the creation of a learning school. Retrieved June $2^{\text {nd }}, 2017$ from http://suthep.crru.ac.th/.

Saisanitsareekul, M. (2014).The School Management Strategy for the Professional Learning Community of Secondary Schools in Benjaburapha Campus, Bangkok. Unpublished dissertation in Educational Administration, Department of Policy Management and Educational Leadership, Faculty of Education, Chulalongkorn University.

Sakwilaiporn, B. .(2010)Relationship between participatory management and the effectiveness of academic work of basic education institutions in Saraburi Educational Service Area Office .IThesis of Master of Educational Technology Administration Rajamangala University of Technology Thanyaburi.

Tatong, R. (2017). Factors Affecting Academic Administration of Schools under Loei Primary Education Service Area Office.2 Thesis of Master of Educational Administration Mahamakut Buddhist University.

Theparee, P. (2014). Development of a community-based learning model for elementary school teachers. Unpublished dissertation in Research and Curriculum Development Srinakharinwirot University.

Thongsawat, S. (2003). Synthesis of research on factors influencing the effectiveness of School Administration. The $4^{\text {th }}$ Hat Yai Conference on "Research for Thai Society Development" on May $10^{\text {th }}$, 2013at Hatyai University, Hat Yai District, Songkhla Province. Academic Project No. 371, page .348-338

Tiansomjai, S. (2013).An effective administration model of primary education service area office. Dissertation of Educational Administration Silpakorn University.

Vadklin, P. (2013). Relationships between participatory management and academic performance in the Bangkok Yai District Office, Bangkok Educational Department. Thesis of Master of Educational Technology Administration, Rajamangala University of Technology Thanyaburi.

Wiratchai, N. (1999). LISREL Model: Statistical Analysis for Research. Bangkok:Publisher of Chulalongkorn University. . (2012). Accurate and modern method of determining sample size.Document of lecture in the Research Zone.National Research Council of Thailand (NRCT).

Wongvanich, S. (.(2001Classroom Action Research. Bangkok: Chulalongkorn University. 